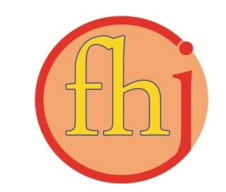

Faletehan Health Journal, 5 (1) (2018) 19-24

https://journal.Ippm-stikesfa.ac.id

ISSN 2088-673X | e-ISSN 2597-8667

\title{
Hubungan Pengetahuan, Sikap, Pelatihan, Pengawasan Dengan Persepsi Tentang Penerapan SM K3
}

\author{
Dina Lusiana Setyowati ${ }^{*}$, Diana Pratiwi ${ }^{1}$, M. Sultan ${ }^{1}$ \\ ${ }^{1}$ Fakultas Kesehatan M asyarakat Universitas M ulawarman Jl. Sambaliung Unmul, Samarinda, Indonesia 75119 \\ *Corresponding Author: dina.setyowatik3@gmail.com
}

\begin{abstract}
Abstrak
Sistem Manajemen Keselamatan dan Kesehatan Kerja (SM K3) adalah bagian dari sistem manajemen perusahaan secara keseluruhan dalam rangka pengendalian risiko yang berkaitan dengan kegiatan kerja guna terciptanya tempat kerja yang aman, efisien dan produktif. PT. PLN (Persero) Sektor Mahakam sebagai salah satu perusahaan dengan potensi bahaya dan resiko kecelakaan yang tinggi telah memasukan SM K3 ke dalam sistem manajemen perusahaan meskipun sejauh ini belum ada peninjauan ulang dan pengukuran tentang dukungan tenaga kerja terhadap penerapan SM K3. Tujuan penelitian ini untuk mengetahui faktor yang berhubungan dengan persepsi tenaga kerja tentang SM K3 pada tenaga kerja PT. PLN (Persero) Sektor Mahakam Unit PLTGU Tanjung Batu. Desain penelitian yang digunakan adalah survei analitik dengan metode kuantitatif dan pendekatan cross sectional dengan besar sampel sebanyak 47 tenaga kerja. Penelitian ini menggunakan uji korelasi chi square dengan $\mathrm{Cl}=95 \%$. Hasil penelitian menunjukkan bahwa ada hubungan pengetahuan $(p=0.029)$, sikap $(p=0.002)$, dan pelatihan K3 $(p=0.028)$ dengan persepsi tentang SM K3, sedangkan variabel pengawasan $(p=0.109)$ tidak berhubungan dengan persepsi tenaga kerja tentang penerapan SM K3. Sikap menjadi faktor yang paling berhubungan dengan persepsi tenaga kerja tentang SM K3.
\end{abstract}

Kata Kunci: Persepsi, Pengetahuan, Pelatihan, Sikap, SM K3

\begin{abstract}
Occupational Safety and Health Management System (SM K3) is part of company management system as a whole in the framework of risk control related to work activities to create safe, efficient and productive workplace. PT. PLN (Persero) Mahakam Sector has included the OSHM S in its corporate management system. However, there has not been any review and assessment to the extent how the workers give support to the OSHM S. This research aims to find out the factors which influence the perception of the workers toward the OSHMS. The design of this research was analytic survey with quantitative method and using cross sectional approach with the total sample are 47 workers. This research applied correlation test of chi square with $95 \% \mathrm{Cl}$. The research findings showed that there was a correlation between knowledge $(p=0.029)$, attitudes $(p=0.002)$ and OSH training $(p=0.028)$ and the perception toward the OSHM S. Supervision ( $p=0.109$ ) didn't have a correlation with the workers perception. Attitudes about OSH becomes the most influential factor in the perception of workers on OSHMS.
\end{abstract}

Keywords: Perception, Knowledge, Training, Attitude, OHSM S 


\section{Pendahuluan}

Program pembangunan nasional memasuki era industrialisasi ditandai dengan meningkatnya pertumbuhan industri, sehingga perlu diimbangi dengan peningkatan kualitas tenaga kerja dan pelaksanaan Sistem Manajemen Keselamatan dan Kesehatan Kerja (SMK3). Dalam UU No. 23 tahun 1992 tentang kesehatan, Pasal 23 dinyatakan bahwa upaya Keselamatan dan Kesehatan Kerja (K3) harus diselenggarakan di semua tempat kerja. Selain itu, dalam Peraturan Pemerintah Republik Indonesia No.50 tahun 2012 pasal 5 dinyatakan bahwa setiap perusahaan wajib menerapkan SMK3. Tujuan utama penerapan SMK3 adalah menciptakan suatu sistem manajemen kesehatan dan keselamatan kerja di tempat kerja dengan melibatkan unsur manajemen, tenaga kerja, kondisi dan lingkungan kerja yang terintegrasi dalam rangka mencegah dan mengurangi kecelakaan dan penyakit akibat kerja, serta terciptanya tempat kerja yang aman, efisien dan produktif. Suatu sistem manajemen dapat berjalan dengan baik bila menjalankan fungsi manajemen sesuai dengan teori Handoko (2012) bahwa fungsi manajemen terdiri dari perencanaan (planning), pengorganisasian (organizing), pelaksanaan (actuating), pengendalian (controling) (Handoko, 2012). Begitu juga penerapan SMK3 harus melibatkan unsur dan fungsi manajemen yaitu perencanaan program K3, pengorganisasian, pelaksanaan program serta pengendalian, sehingga tujuan penerapan SMK3 dapat tercapai.

Berdasarkan data PT. Sucofindo bahwa di Indonesia terdapat lebih dari 1.850 perusahaan dengan berbagai jenis sektor industri, lembaga pemerintahan, sektor pertambangan dan sejumlah industri lain. Pada tahun 2017 sebanyak 455 perusahaan memperoleh penghargaan atas komitmennya terhadap pelaksanaan Keselamatan dan Kesehatan Kerja (K3), jumlah penerima sertifikat ini meningkat dibandingkan tahun 2016 yakni 347 perusahaan, namun jumlah ini masih sangat rendah yaitu $24 \%$ dari jumlah perusahaan yang ada di Indonesia. Perusahaan yang mendapatkan penghargaan ini adalah perusahaan yang melaksanakan audit SMK3 dengan auditor dari PT Sucofindo (Sucofindo, 2017). Hal ini menunjukkan bahwa kenyataan di lapangan masih banyak perusahaan yang tidak memasukkan Keselamatan dan Kesehatan Kerja (K3) ke dalam fungsi sistem manajemen perusahaan (Estiawan, 2013).

Seperti disebutkan di atas bahwa salah satu tujuan dari penerapan Keselamatan dan Kesehatan Kerja adalah mencegah terjadinya kecelakaan kerja. Berdasarkan Data dari Badan Penyelenggara Jaminan Sosial (BPJS) Ketenagakerjaan mencatat angka kecelakaan kerja di Indonesia cenderung terus meningkat. Sebanyak 123 ribu kasus kecelakaan kerja tercatat sepanjang 2017. Berdasarkan data statistik BPJS Ketenagakerjaan terjadi peningkatan kecelakaan kerja sekitar $20 \%$ dibandingkan 2016 secara nasional. Total kecelakaan kerja pada 2017 sebanyak 123 ribu kasus dengan nilai klaim Rp 971 miliar lebih. Angka ini meningkat dari tahun 2016 dengan nilai klaim hanya Rp 792 miliar lebih (Saut, 2017). Tingkat keparahan kecelakaan kerja diseluruh dunia pada umumnya dan di Indonesia pada khususnya masih cukup tinggi. Tingginya kecelakaan kerja disebabkan perusahaan belum sepenuhnya menerapkan Sistem Manajemen Keselamatan dan Kesehatan Kerja (SMK3) (Rosidi, 2015).

PT. PLN (Persero) Sektor Mahakam merupakan perusahaan yang bergerak dalam bidang kelistrikan dan menyuplai pasokan listrik hingga ke seluruh wilayah Kalimantan Timur. Kegiatan operasionalnya mempunyai risiko bahaya dan kecelakaan kerja, sehingga PT. PLN (Persero) Sektor Mahakam mempunyai kewajiban untuk menjamin Keselamatan dan Kesehatan Kerja (K3) tenaga kerja dengan menerapkan SMK3. Demi terciptanya lingkungan kerja yang aman dan sehat di lingkungan PT. PLN (Persero) Sektor Mahakam unit PLTGU Tanjung Batu maka tidak hanya komitmen dari pihak manajemen tetapi juga harus terjadi sinergi diantara seluruh elemen perusahaan baik dari manajemen puncak sampai ke tingkat pekerja. Sinergi akan terjadi apabila masing-masing mempunyai pemahaman atau persepsi yang sama tentang pentingnya pelaksanaan K3 di perusahaan dalam bentuk penerapan SMK3. Pemahaman penerapan SMK3 ini dipengaruhi oleh beberapa faktor sesuai dengan fungsi manajemen yaitu perencanaan (planning), pengorganisasian (organizing), pelaksanaan (actuating), dan pengendalian (controling). Oleh karena itu penelitian ini dilakukan untuk mengetahui hubungan antara pengetahuan, sikap, pelatihan 
Faletehan Health Journal, 5 (1) (2018) 19-24 https://journal.Ippm-stikesfa.ac.id ISSN 2088-673X | 2597-8667

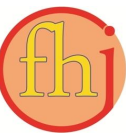

$\mathrm{K} 3$, pengawasan $\mathrm{K} 3$ dengan persepsi tentang penerapan SMK3.

\section{Metode Penelitian}

Jenis penelitian ini adalah penelitian kuantitatif dengan desain cross sectional study. Populasi dan sampel penelitian ini adalah tenaga kerja PT. PLN (Persero) Sektor Mahakam Unit PLTGU Tanjung Batu berjumlah 47 orang. Teknik pengambilan sampel menggunakan total populasi sehingga jumlah sampel pada penelitian ini adalah 47 orang. Variabel bebas dalam penelitian ini adalah pengetahuan, sikap, pelatihan K3, dan pengawasan. Variabel terikat adalah persepsi tentang SMK3. Pengumpulan data menggunakan kuesioner yang disusun sendiri oleh peneliti dan telah dilakukan uji validitas kepada 15 orang tenaga kerja PLTD Karang Asam. Analisis data menggunakan program software meliputi analisis univariat, dan bivariat (uji chi square -pada $\alpha 5 \%$ ).

\section{Hasil dan Pembahasan}

\section{Distribusi Frekuensi Variabel Penelitian}

Hasil Penelitian didapatkan bahwa responden penelitian ini mayoritas pada kelompok umur antara 20 - 26 tahun sekitar 55.3\%, 97.9\% berjenis kelamin laki - laki, telah menyelesaikan pendidikan dasar 9 tahun sekitar 55.3\%, mempunyai masa kerja $<5$ tahun, mempunyai status pekerjaan tetap $85.1 \%$ dan bekerja di unit operasi dan produksi sebanyak $44.7 \%$ dapat dilihat pada Tabel 1 .

Hasil penelitian menunjukkan bahwa mayoritas responden mempunyai pengetahuan kurang sebesar 55\%. Responden menyatakan pedoman pelaksanaan SMK3 dapat dilaksanakan secara mandiri oleh perusahaan, didalam pembuatan perumusan kebijakan K3 dapat dilaksanakan oleh pihak manajemen tanpa keterlibatan tenaga kerja, perencanaan K3 tidak perlu adanya penilaian dan peninjauan awal K3, analisis situasi lingkungan hanya sebatas menggugurkan kewajiban tanpa adanya tindak lanjut dan rencana kerja P2K3 disamakan saja dengan rencana kerja tahun-tahun sebelumnya.

Sebanyak 53\% responden mempunyai sikap tentang K3 kurang atau negatif. Responden menyatakan bahwa merasa tidak dilibatkan dalam penetapan kebijakan $\mathrm{K} 3$, penilaian kinerja tidak berdampak atau bermanfaat, pengawasan untuk mengukur kemampuan tenaga kerja, evaluasi SMK3 tidak perlu dilaksanakan karena mengganggu konsentrasi saat bekerja, audit SMK3 tidak perlu dilaksanakan secara rutin dan terjadwal hanya perlu dilaksanakan jika diperlukan saja, dan peninjauan ulang SMK3 tidak perlu dilaksanakan karena hanya membuang waktu.

Tabel 1. Distribusi Berdasarkan Karakteristik Responden

\begin{tabular}{|c|c|c|}
\hline Variabel & $\mathbf{F}$ & $\%$ \\
\hline \multicolumn{3}{|l|}{ Umur (tahun) } \\
\hline $20-26$ & 26 & 55.3 \\
\hline $27-33$ & 11 & 23.4 \\
\hline $34-40$ & 6 & 12.8 \\
\hline $41-47$ & 1 & 2.1 \\
\hline$>47$ & 53 & 6.4 \\
\hline \multicolumn{3}{|l|}{ Jenis Kelamin } \\
\hline Pria & 46 & 97.9 \\
\hline Wanita & 1 & 2.1 \\
\hline \multicolumn{3}{|l|}{ Pendidikan Terakhir } \\
\hline SMA & 26 & 55.3 \\
\hline D3 & 11 & 23.4 \\
\hline $\mathrm{S} 1$ & 10 & 21.3 \\
\hline \multicolumn{3}{|l|}{ Masa Kerja } \\
\hline$<5$ tahun & 32 & 68.1 \\
\hline$\geq 5$ tahun & 15 & 31.9 \\
\hline \multicolumn{3}{|l|}{ Status Pekerjaan } \\
\hline Kontrak & 7 & 14.9 \\
\hline Tetap & 40 & 85.1 \\
\hline \multicolumn{3}{|l|}{ Unit Kerja } \\
\hline Administrasi & 6 & 12.8 \\
\hline Maintenance & 11 & 23.4 \\
\hline Operator WTP \& PDC & 21 & 19.1 \\
\hline Operasi dan Produksi & 9 & 44.7 \\
\hline \multicolumn{3}{|l|}{ Pengetahuan } \\
\hline Kurang & 26 & 55 \\
\hline Baik & 21 & 45 \\
\hline \multicolumn{3}{|l|}{ Sikap } \\
\hline Kurang & 25 & 53 \\
\hline Baik & 22 & 47 \\
\hline \multicolumn{3}{|l|}{ Pelatihan K3 } \\
\hline Kurang & 28 & 60 \\
\hline Baik & 19 & 40 \\
\hline \multicolumn{3}{|l|}{ Pengawasan } \\
\hline Kurang & 24 & 51 \\
\hline Baik & 23 & 49 \\
\hline \multicolumn{3}{|l|}{ Persepsi tentang SMK3 } \\
\hline Kurang & 24 & 51 \\
\hline Baik & 23 & 49 \\
\hline
\end{tabular}


Mayoritas responden (60\%) kurang mendapatkan pelatihan K3. Responden menyatakan bahwa merasa lebih senang jika pelatihan dilaksanakan secara eksternal yaitu diluar jam kerja dan perusahaan, metode dan materi pelatihan kurang sesuai dan sulit dimengerti, tidak ada evaluasi setelah adanya pelatihan, dan jadwal pelatihan juga tidak menentu dan sering berubah. Sebanyak 51\% responden menyatakan kurang tentang pengawasan K3. Responden menyatakan jika pengawasan dilakukan hanya untuk mencari-cari kesalahan, mengukur hasil pekerjaan serta membanding-bandingkan hasil pekerjaan tenaga kerja, sehingga responden menyatakan bahwa pengawasan tidak perlu dilaksanakan karena membuat responden risih dan tidak nyaman, tidak dapat memberikan motivasi bagi tenaga kerja dan dapat menimbulkan diskriminasi.

\section{Hasil Analisis Bivariat}

Berdasarkan hasil analisis bivariat menunjukkan bahwa pengetahuan berhubungan dengan persepsi tentang SMK3 ( $\mathrm{p}=0.029)$. Sikap berhubungan dengan persepsi tentang SMK3 $(\mathrm{p}=0.002)$. Pelatihan K3 berhubungan dengan persepsi tentang SMK3 $(\mathrm{p}=0.028)$. Pengawasan tidak berhubungan $(\mathrm{p}=0.109)$ dengan persepsi tentang SMK3 dapat dilihat pada Tabel 2.

\section{Hubungan Pengetahuan dengan Persepsi Tentang Penerapan SMK3}

Berdasarkan hasil penelitian pengetahuan tentang SMK3 merupakan variabel yang berhubungan dengan persepsi responden tentang penerapan SMK3 yaitu dengan nilai $\mathrm{p}=0.029$. Berdasarkan data menunjukkan bahwa responden tidak mengetahui bahwa dalam perumusan kebijakan K3, perencanaan $\mathrm{K} 3$, penilaian dan peninjauan awal $\mathrm{K} 3$, analisis situasi lingkungan kerja harus melibatkan tenaga kerja karena perencanaan K3 seharusnya merupakan hasil dan kelanjutan dari penilaian dan peninjauan awal K3, sehingga fungsi manajemen dapat berjalan dengan baik. Persepsi responden yang kurang baik tentang penerapan Sistem Manajemen Keselamatan dan Kesehatan Kerja dipengaruhi oleh karakteristik individu, kebutuhan akan pengenalan tentang $\mathrm{K} 3$, dan kondisi emosional individu. Selain itu juga juga disebabkan informasi dan pengetahuan tentang SMK3 kurang disebarluaskan di kalangan pekerja lapangan.

Hal ini sesuai dengan teori yang dikemukakan oleh Wirawan bahwa persepsi seseorang tidak timbul begitu saja. Persepsi bisa digunakan seseorang untuk memandang atau menilai suatu objek. Persepsi seseorang terhadap suatu objek akan dipengaruhi oleh sejauh mana pemahaman terhadap objek tersebut (Wirawan, 2009).

Tabel 2. Hasil Analisis Bivariat Variabel Independen dan Dependen (persepsi tentang SMK3) pada Tenaga Kerja PT. PLN (Persero) Sektor Mahakam Unit PLTGU Tanjung Batu

\begin{tabular}{|c|c|c|c|c|c|}
\hline \multirow[t]{3}{*}{ Variabel } & \multicolumn{4}{|c|}{ Persepsi tentang SMK3 } & \multirow[t]{3}{*}{$\rho$} \\
\hline & \multicolumn{2}{|c|}{ Kurang } & \multicolumn{2}{|c|}{ Baik } & \\
\hline & $\mathbf{n}$ & $\%$ & $\mathbf{n}$ & $\%$ & \\
\hline Pengetahuan & & & & & $0.029 *$ \\
\hline Kurang & 17 & 65.4 & 9 & 34.6 & \\
\hline Baik & 7 & 33.3 & 14 & 66.7 & \\
\hline Sikap & & & & & $0.002 *$ \\
\hline Kurang & 18 & 72.0 & 7 & 28.0 & \\
\hline Baik & 6 & 27.3 & 16 & 72.7 & \\
\hline Pelatihan K3 & & & & & $0.028 *$ \\
\hline Kurang & 18 & 64.3 & 10 & 35.7 & \\
\hline Baik & 6 & 31.6 & 13 & 68.4 & \\
\hline Pengawasan & & & & & 0.109 \\
\hline Kurang & 15 & 62.5 & 9 & 37.5 & \\
\hline Baik & 9 & 39.1 & 14 & 60.9 & \\
\hline
\end{tabular}

Ket: * Variabel yang berhubungan 
Faletehan Health Journal, 5 (1) (2018) 19-24

https://journal.Ippm-stikesfa.ac.id

ISSN 2088-673X| 2597-8667

Sejalan dengan teori Rahmat (2005) yang menyatakan bahwa persepsi seseorang sangat dipengaruhi oleh tingkat pengetahuan mereka sendiri. Semakin tinggi tingkat pengetahuan seseorang maka akan semakin baik dalam mempersepsikan sesuatu. Persepsi antara satu karyawan/tenaga kerja dengan tenaga kerja lain akan berbeda meskipun memiliki tingkat pendidikan sama (Rahmat, 2005). Hasil penelitian ini sesuai dengan penelititan yang dilakukan oleh Almani (2013) pada karyawan unit produksi PT. Semen Tonasa yang menyatakan terdapat hubungan antara tingkat pengetahuan tenaga kerja dengan persepsi tentang program K3 dengan nilai $\rho 0.036$ yang berarti hubungan antara tingkat pengetahuan dan persepsi tentang penerapan program K3 cukup erat keterkaitannya (Almani, 2013).

\section{Hubungan Sikap dengan Persepsi Tentang Penerapan SMK3}

Responden memiliki sikap yang kurang/negatif terhadap penerapan SMK3. Sikap negatif tenaga kerja ini dikarenakan responden merasa tidak dilibatkan dalam penetapan kebijakan K3, sehingga responden menganggap bahwa penilaian kinerja, evaluasi SMK3, Audit SMK3 dan peninjauan ulang SMK3 tidak perlu dilaksanakan karena hanya membuang waktu dan menganggu konsentrasi mereka dalam bekerja. Sikap merupakan aspek dari persepsi. Sikap terbentuk dari stimuli seseorang yang kemudian menjadi sebuah persepsi. Stimuli yang diterima oleh tiap individu tidak selalu sama sehingga menimbulkan persepsi yang berbeda antar individu. Itulah sebabnya, sikap setiap orang berbeda namun kebanyakan memiliki arah hubungan yang sama semakin baik sikap seseorang maka semakin baik persepsi terhadap sesuatu begitupun sebaliknya (Ajzen, 2008). Menurut Handoko (2012), persepsi orang sangat berpengaruh pada perilakunya. Sesorang yang yang memiliki persepsi positif umumnya memiliki perilaku positif. Proses persepsi dapat menambah dan mengurangi kejadian senyatanya yang diinderakan oleh seseorang (Handoko, 2012). Hasil penelitian ini sejalan dengan penelitian yang dilakukan oleh Tumbelaka (2013) yang menyimpulkan bahwa ada hubungan antara sikap dengan penerapan program K3. Hasil penelitian tersebut adalah signifikansi dengan menggunakan uji statistik pearson product moment dengan nilai $\rho$ sebesar 0.036 dimana sikap ternyata memiliki hubungan yang cukup erat dengan penerapan program K3 (Tumbeleka, 2013).

\section{Hubungan Pelatihan dengan Persepsi Tentang Penerapan SMK3}

Responden menyatakan bahwa metode dan materi pelatihan yang diikuti kurang sesuai dan sulit dimengerti, serta tidak ada evaluasi setelah adanya pelatihan. Sedangkan (Soeprihanto, 2009) menyatakan bahwa penyelenggaraan program pelatihan merupakan salah satu kebutuhan yang harus diperhatikan untuk membina ketrampilan karyawan. Pengetahuan dan ketrampilan dapat diperoleh melalui pendidikan dan pelatihan. Pelatihan yang diberikan kepada karyawan harus di sesuaikan dengan peranan dan tanggung jawab karyawan. Pengetahuan dan ketrampilan dibidang K3 yang tinggi dapat membangun persepsi karyawan di bidang K3 menjadi lebih baik. Jika persepsi di bidang K3 sudah baik, maka akan berpengaruh kepada sikap dan tindakan dalam menangani K3 menjadi lebih baik pula. Hal ini juga tergantung kemampuan daya serap karyawan dalam menerima dan memahami informasi K3 yang diberikan kepadanya (Hamalik, 2011). Hasil penelitian ini sesuai dengan penelitian yang dilaksanakan oleh Agusta (Agusta, 2013) penelitian yang dilakukan di CV. Haragon Surabaya memiliki nilai koefisien regresi pelatihan sebesar 0.448 yang menunjukan bahwa adanya arah pengaruh positif pelatihan dengan persepsi yang berpengaruh terhadap kinerja karyawan.

\section{Hubungan Pengawasan dengan Persepsi Tentang Penerapan SMK3}

Menurut PP RI No 50 Tahun 2012 tentang SMK3 menyatakan bahwa pengawasan adalah suatu pekerjaan yang berarti mengarahkan yaitu memberi tugas, menyediakan instruksi, pelatihan dan nasihat kepada individu juga termasuk mendengarkan dan memecahkan masalah yang berhubungan dengan pekerjaan serta menanggapi keluhan bawahan. Tujuan dari pengawasan memotivasi pekerja bekerja secara benar dan memastikan pekerja tahu bagaimana melakukan pekerjaanya. Berdasarkan hasil penelitian ini, tidak ada hubungan antara pengawasan dengan persepsi tenaga kerja tentang SMK3. Responden menyatakan bahwa pengawasan tidak dilakukan secara sistematis dan hanya untuk mencari kesalahan responden dalam bekerja sehingga 
pengawasan ini tidak berdampak pada persepsi responden tentang pelaksanaan SMK3. Selain itu hal ini dapat disebabkan juga karena faktor-faktor lain, seperti pengetahuan, sikap, pelatihan, niat, dan faktor lainnya. Selain beberapa faktor tersebut juga dapat dipengaruhi oleh item diluar variabel pengawasan. Item tersebut seperti besar kecilnya pemberian kompensasi, keteladanan pimpinan, adanya peraturan yang pasti, keberanian pimpinan dalam mengambil keputusan, komunikasi, dan motivasi. Hasil penelitian ini tidak sesuai dengan penelitian yang pernah dilaksanakan oleh Habe (2012) di CV. Kencana Baru dimana terdapat hubungan positif antara pengawasan dengan disiplin kerja karyawan dengan nilai $r=0.75$ lebih besar dari $\mathrm{r}$ tabel dengan tingkat keyakinan 95\% sebesar 0.374 (Hazairin, 2012).

\section{Simpulan}

Kesimpulan dari penelitian ini adalah pengetahuan, sikap, pelatihan K3 merupakan faktor yang berhubungan dengan persepsi tenaga kerja tentang SMK3. Sikap menjadi faktor yang paling berpengaruh pada persepsi tenaga kerja tentang SMK3. Saran dalam penelitian ini adalah perusahaan agar mengadakan sosialisasi tentang SMK3 baik manfaat bagi perusahaan dan karyawan, peran serta dalam SMK3 hingga update peraturan dan pedoman pelaksanaan secara rutin dan terjadwal kepada seluruh karyawan.

\section{Daftar Pustaka}

Agusta, L. (2013). Pengaruh Pelatihan dan Motivasi Kerja terhadap Kinerja Karyawan CV Haragon Surabaya. Agora, Vol 1 No.3.

Ajzen. (2008). Attitude \& Attitude Change. Crawnd: Psychology Press.

Almani. (2013). Faktor yang Berhubungan dengan persepsi Karyawan Unit Produksi IV terhadap Sistem Manajemen Keselamatan dan Kesehatan kerja di PT Semen Tonasa. Dipetik Maret 14, 2015, dari http://repository.unhas.ac.id/handle/1234567 89

Estiawan. (2013). Analisisi Sistem Manajemen K3 terhadap kepuasan kerja karyawan, Studi pada PT. PJB UP Brantas. Malang: Universitas Brawijaya Malang.
Hamalik. (2011). Manajemen Pelatihan Ketenagakerjaan. Jakarta: Bumi Aksara.

Handoko. (2012). Persepsi Pekerja tentang Gema Daya K3 di Bagian Produksi PT. Indofood CBP Sukses Makmur Tbk Cabang Medan. Medan: Univeritas Sumatera Utara.

Handoko, T. H. (2012). Manajemen Personalia dan Sumber Daya Manusia. Yogyakarta: BPFE.

Hazairin. (2012). Hubungan Pengawasan dengan Disiplin Kerja Karyawan pada CV Kencana Baru Bandar Lampung. Fakultas Ekonomi USBRJ, 1 No 2 : 1-7, Vol.1 No 2: 1-7.

Peraturan Pemerintah Republik Indonesia No 50 Tahun 2012 Tentang Penerapan Sistem manajemen Keselamatan dan Kesehatan Kerja. (2012). Jakarta: Pemerintah Republik Indonesia.

Rahmat. (2005). Metode Penelitian Komunikasi. Bandung: PT. Remaja Rosdakarya.

Rosidi, I. (2015). Kemenakertrans targetkan perusahaan terapkan Sistem Manajemen Keselamatan dan Kesehatan Kerja (SMK3). Dipetik Februari 12, 2017, dari Menakertrans: Http:/econpmy.okezone.com/

Saut, P. D. (2017). Angka Kecelakaan Kerja RI Meningkat ke 123 Ribu Kasus di 2017. Dipetik Februari 24, 2018, dari https://finance.detik.com/moneter/d3853101/angka-kecelakaan-kerja-rimeningkat-ke-123-ribu-kasus-di-2017

Soeprihanto. (2009). Penilian Kinerja dan Pengembangan Karyawan. Yogyakarta: BPFE.

Sucofindo, P. (2017). Sucofindo Audit 455 Perusahaan Peraih Sertifikat SMK3. Dipetik 2 24, 2017, dari http://pressrelease.id/release/ sucofindo-audit-455-perusahaan-peraihsertifikat-smk3

Tarwaka. (2014). Keselamatan dan Kesehatan Kerja. Surakarta: Harapan Press.

Tumbeleka. (2013). Studi Korelasi Antara Sikap Pekerja dengan Penerapan Program SMK3. 1 No 5, Vol. 1 No 5.

Wirawan. (2009). Evaluasi Kinerja Sumber Daya Manusia. Teori Aplikasi dan Penelitian. Jakarta: Salemba Empat. 